\title{
Case Study on Solar-Powered Hospital Elevator to Push Green Energy for the Use of Alternative Energy Sources- Sunlight
}

\author{
Vaibhav A. Chilate \\ Department of Mechanical \\ Engineering, NIT-Warangal, India
}

\author{
P.K. Jayakumar \\ Principal Scientist, NFTDC, \\ Hyderabad, India
}

\author{
K.V. Sai Srinadh \\ Professor, Department of Mechanical \\ Engineering, NIT-Warangal, India
}

*Corresponding Author: Vaibhav A. Chilate, +91-9420383267

\begin{abstract}
A case study for using solar power for emergency lift operation in hospital is discussed. The details of load estimate PV array, battery and inverter selection and sizing show that less than 30 $\mathrm{m} 2$ roof area and accessories are sufficient to facilitate the system. Further, economic feasibility analysis using RET screen shows a fast break even time period less than 4 years. The article describes the basic configuration selection and sizing of the solar PV system.
\end{abstract}

\section{Keywords}

Solar-powered hospital elevator, photovoltaic (PV), array, battery, charge controller, inverter, load, Balance of system.

\section{INTRODUCTION}

An emergency power system is an independent source of electrical power that supports important electrical systems on loss of normal power supply. Emergency power systems are installed to protect life and property such as hospitals, scientific laboratories, data centres etc. from the consequences of loss of primary electric power supply. Emergency power systems can rely on engine-powered generator, battery operated inverter.

An engine-powered generator is the most common source of power for emergency and standby power systems. For most commercial and industrial power systems these will be enginegenerator sets, with the prime-mover and the generator built into a single unit. Diesel engines are the most popular choice of prime mover for generators, due to the cost of the diesel engines as compared to other forms of power and the relative ease of application. Following considerations are required for diesel generator- the combustion and cooling air required by the generator and prime mover, as well as the provisions for the removal of exhaust gasses. Further, noise reduction, fuel supply, and Engine maintenance must also be considered.

A second alternative for emergency system power is a battery operated inverter. An inverter is a very easy and inexpensive solution for power demands in the 200 -watt range.
Even for elaborate system, inverters can be a good option up to about $5 \mathrm{KW}$, although they tend to get expensive above this range. Inverters are silence, and maintenance free, because these advantages battery bank inverter are widely used over engine operated generator system in power emergency.

Solar PV systems are electrical power generation system that produces energy. PV systems can be designed to supply power to any type of electrical load at any service voltage. The major components in PV systems is an array of PV modules that produces dc electricity when expose to sun light. Other major components may include power conditioning equipment, energy storage devices, other power sources and electrical loads. Power conditioning equipments includes inverter, charge and load controllers, and energy storage device include mainly batteries.

There are two main types of solar PV systems: gridconnected (or grid-tied) and stand-alone solar PV systems.

\subsection{Grid type Solar PV System}

A building has two parallel power supplies, one from the solar PV system and the other from the power grid. The combined power supply feeds all the loads connected to the main terminal. The ratio of solar PV supply to power grid supply varies, depending on the size of the solar PV system.

Whenever the solar PV supply exceeds the building's demand, excess electricity will be exported into the grid. When there is no sunlight to generate PV electricity at night, the power grid will supply all of the building's demand.

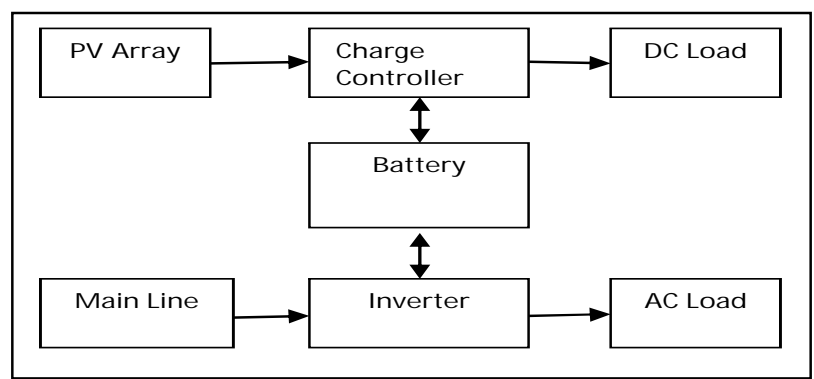

Figure 1 Grid type Solar PV System. 


\subsection{Stand-alone Solar PV System}

Off-grid solar PV systems are applicable for areas without power grid. Currently, such solar PV systems are usually installed at isolated sites where the power grid is far away, such as rural areas or off-shore islands. But they may also be installed within the city in situations where it is inconvenient or too costly to tap electricity from the power grid.

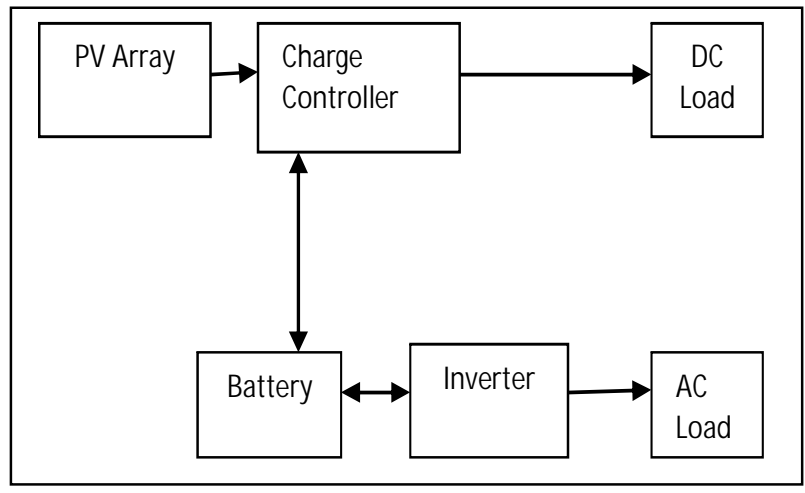

Figure 2 Stand-alone solar PV systems

Solar-powered elevator can be off-grid or hybrid with main connection. In this paper hybrid management system expounded, photovoltaic panels (PV-panels) and their connection interfaces are supplied by the building's main connection which optimized energy supply with solar energy as the main source. The elevator uses a smart power supply - renewable energy from sunlight and a back-up from the grid. It also optimizes the use of clean solar energy by controlling the energy distribution. It lowers energy costs by making sure that the Energy Storage Device (ESD) is charged with solar energy as much as possible.

Technical Specification:

Table 1 Technical Specification of a hospital elevator

\begin{tabular}{|l|l|}
\hline \multicolumn{1}{|c|}{ Descriptions } & \multicolumn{1}{c|}{ Specification } \\
\hline Type of Lift & Hospital Elevator \\
\hline Capacity & $400-675 \mathrm{Kg}$. (6-9 persons) \\
\hline Speed & $1 \mathrm{~m} / \mathrm{s}$ \\
\hline No. of stops & Maximum 11 stops \\
\hline Travel height & 15 meter, G +5 floor \\
\hline Drive system & $\begin{array}{l}\text { variable voltage variable } \\
\text { frequency }\end{array}$ \\
\hline Power Supply & $\begin{array}{l}\text { Single-phase } 230 \mathrm{~V}, 50 \text { cycle } \\
\text { A.C }\end{array}$ \\
\hline
\end{tabular}

\begin{tabular}{|l|l|} 
Motor & $8 \mathrm{KW}$ \\
\hline N.F.B Rated Current & $35 \mathrm{~A}$ \\
\hline Transformer Capacity & $10 \mathrm{KVA}$ \\
\hline Cabinet & $\begin{array}{l}\text { Lockable cabinet } \\
400 \times 300 \times 2000 \mathrm{~mm}(\mathrm{w} \mathrm{x} \mathrm{d} \mathrm{h})\end{array}$ \\
\hline Battery & $\begin{array}{l}\text { Covering up to } 200 \text { trips without } \\
\text { charging }\end{array}$ \\
\hline Location & $\begin{array}{l}\text { Technical room or public space } \\
\text { Max. } 30 \mathrm{~m} \text { distance to drive } \\
\text { system }\end{array}$ \\
\hline
\end{tabular}

\subsection{Interfacing component in Solar PV System for solar-powered hospital elevator}

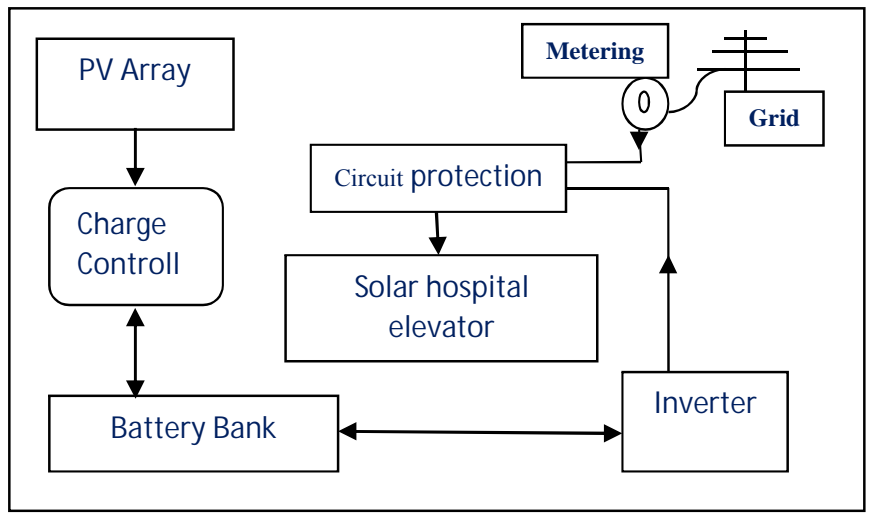

Figure 3 Interfacing components in Solar PV System for solar hospital elevator

Solar PV system includes different components that should be selected according to system type, site location and applications. The major components for solar PV system are solar charge controller, inverter, battery bank, auxiliary energy sources and loads.

\subsection{Power management system}

A hybrid power system consists of a combination of two or more power generation technologies. In this paper we considered "Photovoltaic cell" and "Grid power" for generation of energy. The power for the load demand can be effectively delivered and supplied by the proposed hybrid power generation system with proper control and effective coordination among various subsystems-grid system, PV system, and battery.

The power management system (PMS) is developed to control the flow of energy of individual power generating system and battery. The PMS is designed such that the use of battery is as low as possible. The grid/PV hybrid system works as a dominant 
system and battery as a backup. When the total power generation of the hybrid system (i.e., combination of grid and PV system) is higher than the load demand, then the excess power is used to charge the battery and to feed the power to the load of selected area. As the hydro and PV systems are intermittent in nature, the variation in the power generation will be according to seasonal variation. When power fails, the battery is allowed to share the required power to the elevator. The power management of the hydro energy system depends on the state of charge (SOC) of the battery. In order to obtain efficient power distribution among the hydro system, PV system, and battery, the battery should operate in the high efficiency region and battery SOC should be maintained at a reasonable level that is between $40 \%$ and $80 \%$.

\subsection{Operational scenarios}

In day time at pick hours of sunny day if battery is fully charged when grid power is on, power manager forces the system to pump the power generated from the PV panels to medium size supplementary load such as air conditioning and ventilation systems but at power failure course, connections will switch from other supplementary loads to the emergency hospital elevator solely, and it will relay on available power in battery. Further, if the battery is not fully charged when power is failure, system supplies the power only for elevator and charges the battery pack with the extra energy from panels.

In night time, other supplementary loads must not connect with the battery bank. And battery must keep safely stored for emergency need. When grid power fails load is supplied from battery if the SOC is over a minimum value.

\section{LOAD ESTIMATE}

The daily load sketches were determined by calculating the power demand (KWh). Normal working time for solar elevator counts in number of round trips. According to a technical report [3] by American society for healthcare engineering, found that the trip frequency of hospital elevator drop down by $50 \%$ after power failure for managing hospital emergency power. In given case study, hospital elevator takes as an average 3 min for one round trip. If power failure for 3 hours, it will take nearly 30 emergency trips.

Total power required to cater an elevator for 3 hours in emergency

$=30 \mathrm{x}$ power consume in single trip

$=30 \times 0.4 \mathrm{kWh}=12 \mathrm{kWh}$

Thus, estimated load is $12 \mathrm{kWh}$.

Since the total ac-load is greater than $5 \mathrm{~kW}$, the system voltage selected is $48 \mathrm{vdc}$ [4].

\section{SELECTION OF PV MODULE}

The solar cell is the basic unit of a PV system. An individual solar cell produces direct current and power typically between 1 and $2 \mathrm{~W}$, hardly enough to power most applications. Thus, for actual usage, the solar cells are interconnected in series/parallel combinations to form a PV module. For large-scale generation of solar electricity the solar panels are connected together into a solar array.
A site assessment for PV arrays involves Shading, array orientation, array location, and array mounting $[1,2]$

\section{a) Shading}

This is important, as the output of PV modules may be significantly impaired by even a small amount of shading on the array. A minimum of six hours of unshaded operation is still important for best system performance, especially between the hours of 9 a.m. and 3 p.m. solar time.

b) Array Orientation

PV arrays should orient toward the solar window to receive the maximum amount of solar radiations available at a site, at any time. The closer an array surface faces the sun throughout every day and over a year without a being shaded, the more energy that system will produce.

c) Array Location

Arrays can be mounted on roofs, racks, and poles. The installer needs to determine or verify which method is best for the location of the installation. Roofs are popular locations for PV array installations. Roof-mounted arrays provide protection for the modules from many forms of physical damage, and provide better sun exposure.

d) Array Mounting Methods

Common PV array mounting methods include integral mounting, standoff mounting, rack mounting, and pole mounting. Integral mounting is where the modules are integrated into the roofing or exterior of the building itself. Standoff mounting is where modules are mounted above and parallel to the roof surface. The most common mounting method on a sloped roof is the standoff mounting method, as this method provides for air circulation behind the modules to reduce the PV module operating temperature.

Rack mounting is typically used for non-tracking systems at ground level and at flat rooftops.

Pole mounting typically used with manufactured rack mounted on top or attached to the side of a steel pole. Pole type arrays are common to stand alone type PV system.

Selecting modules requires an understanding of module attributes and specifications. The most important module characteristics depend on the site and system goals. The ENP Sonne High Quality $180 \mathrm{Watt}, 24 \mathrm{~V}$ monocrystalline module is chosen in this design.

\subsection{Calculate total Watt-hours per day needed from the PV modules}

PV array output power:

$\mathrm{P}_{\mathrm{pv} \text {-array }}=\left[\mathrm{E}_{\mathrm{L}} / \eta_{\text {b.o }} \times \mathrm{K}_{\mathrm{LOSS}} \times \mathrm{H}_{\text {tilt }}\right] \times$ PSI

$\mathrm{E}_{\mathrm{L}}=$ Estimated average daily load energy consumption in $\mathrm{kWh}$

$\eta_{\text {b.o }}=$ Efficiency of balance of system

$\eta$ b.o $=\eta_{\text {invertor }} \times \eta_{\text {wireloss }}(0.855)$

$\mathrm{K}_{\mathrm{LOSS}}=\mathrm{A}$ factor determined by different losses such as module temperature, losses, dust, etc (0.833) 
Case Study on Solar-Powered Hospital Elevator to Push Green Energy for the Use of Alternative Energy Sources-Sunlight

$\mathrm{H}_{\text {tilt }}=$ Average solar radiation in peak sun hour's incident for specified tilt angle. (5.5 hrs)

PSI = Peak solar intensity at the earth surface $\left(1 \mathrm{~kW} / \mathrm{m}^{2}\right) .(1.0)$

Thus, for $12 \mathrm{kWh}$

$\mathrm{P}_{\mathrm{pv}-\mathrm{array}}=3 \mathrm{kw}$

\subsection{Calculate the number of PV panels for the system}

1.1.1 Number of modules in series

$\mathbf{N}_{\text {ms }}=\mathbf{V}_{\text {system }} / \mathbf{V}_{\text {module }}$

$\mathbf{N}_{\mathrm{ms}} \quad=$ Number of modules in series

$\mathbf{V}_{\text {system }}=$ Designed system voltage

$\mathbf{V}_{\text {module }}=$ Nominal module voltage

$\mathbf{N}_{\mathrm{ms}}=\mathbf{2}$

1.1.2 Number of modules in parallel

$\mathrm{N}_{\mathrm{mp}}=\mathrm{P}_{\text {pv-array }} / \mathbf{N}_{\mathrm{ms}} \times \mathrm{P}_{\text {module }}$

$\mathrm{Nmp}=$ Number of modules in parallel

$\mathrm{P}_{\text {module }}=$ Selected module output power

$\mathrm{N}_{\mathrm{mp}}=9$ modules

Total number of modules required $=\mathbf{N}_{\mathbf{m s}} \times \mathbf{N}_{\mathbf{m p}}$

$$
=2 \times 9=18
$$

\section{PV STORAGE SYSTEM}

Batteries of PV systems are subjected to frequent charging and discharging process. Lead acid battery with deep discharge is commonly used for PV applications. Gel type lead acid batteries are used for remote applications where maintenance free operation is required.

For portable applications Nickel-Cadmium or Ni-Metal hydride batteries are used. The life time of the batteries varies from 3 to 5 years. The life time depends on charging/discharging cycles, temperature and other parameters.

The primary functions of a storage battery in a PV system are [6]:

1. Energy Storage and Autonomy: Store electrical energy produced by PV modules and supply energy as needed for the load.

2. Voltage and Current stabilization: To supply power to electrical loads at stable voltages and currents.

3. Supply Surge Currents: Supply high peak operating currents to electrical loads or appliances.
Table 2. Battery types and maintenance characteristics [6].

\begin{tabular}{|c|c|c|c|}
\hline $\begin{array}{l}\text { Battery } \\
\text { Type. }\end{array}$ & Cost & $\begin{array}{l}\text { Deep Cycle } \\
\text { Performance }\end{array}$ & Maintenance \\
\hline \multicolumn{4}{|c|}{ Flooded Lead-Acid } \\
\hline $\begin{array}{l}\text { Lead- } \\
\text { Antimony }\end{array}$ & Low & Good & High \\
\hline $\begin{array}{l}\text { Lead- } \\
\text { Calcium } \\
\text { Open } \\
\text { Vent }\end{array}$ & Low & Poor & Medium \\
\hline $\begin{array}{l}\text { Lead- } \\
\text { Calcium } \\
\text { Sealed } \\
\text { Vent }\end{array}$ & Low & Poor & Low \\
\hline $\begin{array}{l}\text { Lead- } \\
\text { Antimony } \\
\text { /Calcium } \\
\text { Hybrid }\end{array}$ & Medium & Good & Medium \\
\hline \multicolumn{4}{|c|}{ Captive Electrolyte Lead-Acid } \\
\hline Gelled & Medium & Fair & Low \\
\hline $\begin{array}{l}\text { Absorbed } \\
\text { Glass } \\
\text { Mat }\end{array}$ & Medium & Fair & Low \\
\hline \multicolumn{4}{|c|}{ Nickel-Cadmium } \\
\hline $\begin{array}{l}\text { Sealed } \\
\text { Sintered- } \\
\text { Plate }\end{array}$ & High & Good & None \\
\hline $\begin{array}{l}\text { Flooded } \\
\text { Pocket- } \\
\text { Plate }\end{array}$ & High & Good & Medium \\
\hline
\end{tabular}


Table 3. Characteristics comparison in Lead-acid and NiCd battery

\begin{tabular}{|l|c|c|}
\hline \multicolumn{1}{|c|}{$\begin{array}{c}\text { Battery } \\
\text { type }\end{array}$} & Lead-acid & NiCd \\
\hline Cycle time & $\begin{array}{c}600 \text { to } 1500 \\
\text { cycles }\end{array}$ & $\begin{array}{c}1500 \text { to } 3500 \\
\text { cycles }\end{array}$ \\
\hline Efficiency & 83 to $>90 \%$ & $71 \%$ \\
\hline Self-discharge rate & 3 to $10 \%$ & 6 to $20 \%$ \\
\hline Range of operation & -15 to $+50^{\circ} \mathrm{C}$ & -40 to $+45^{\circ} \mathrm{C}$ \\
\hline
\end{tabular}

\subsection{Battery sizing for solar elevator}

The battery type recommended for using in solar PV system is deep cycle battery. Deep cycle battery is specifically designed for to be discharged to low energy level and rapid recharged or cycle charged and discharged day after day for years.

$\mathrm{C}_{\mathrm{x}}=\left[\mathrm{N}_{\mathrm{c}} \times \mathrm{E}_{\mathrm{L}}\right] /\left[\mathrm{DOD}_{\max } \mathrm{X} \mathrm{V}_{\text {system }} \mathrm{X} \eta_{\text {out }}\right]$

$$
\begin{aligned}
& \mathrm{C}_{\mathrm{x}}=\text { Required battery capacity } \\
& \mathrm{N}_{\mathrm{c}}=\text { Number of days of autonomy (4) } \\
& \mathrm{E}_{\mathrm{L}}=\text { Estimated load energy in Wh } \\
& \mathrm{DOD}_{\max }=\text { Maximum depth of discharge }(0.75) \\
& \eta_{\text {out }}=\text { Battery loss }(0.85)
\end{aligned}
$$

thus, $\mathrm{C}_{\mathrm{x}}=1569 \mathrm{Ah}$

Battery's Specification: The battery selected is ROLLS SERIES 4000 BATTERIES, 12MD325P. The battery has a capacity of $325 \mathrm{AH}$ and a nominal voltage of $12 \mathrm{~V}$.

$\mathrm{N}_{\text {breq }}=\mathrm{Cx} /$ Cselected

$\mathrm{N}_{\text {breq }}=$ Number of batteries required

$\mathrm{N}_{\text {breq }}=5$ batteries.

\section{INVERTER}

An inverter's basic function is to "invert" the direct current (DC) output of a photovoltaic (PV) system into alternating current (AC). $\mathrm{AC}$ is the standard used by all commercial appliances, which is why many view solar inverters as the "gateway" between the PV system and the energy off-taker. Inverters have evolved from providing just the one important function of inverting the electrical current to a number of other capabilities and services. Every inverter should provide options for extra tools and services such as low-loss conversion, power optimization, monitoring and securing, communication, temperature management, protection.

Inverters can be classified into two broad categories:

\section{A) Stand-Alone Inverters}

These inverters are meant to operate isolated from the electrical distribution network and require batteries for proper operation. The batteries provide a constant voltage source at the DC input of the inverter. Inverters can be classified briefly as:

- Square Wave Inverters

- Modified Sine Wave Inverters

- Sine wave inverters (quasi-sine wave).

\section{B) Grid-Tied Inverters}

These inverters operate coupled to the electric distribution network and therefore must be able to produce almost perfect sinusoidal voltages and currents. The operating requirements for these types of inverters are in most cases determined by the local utilities, yet most utilities rely on existing standards to determine feasible technologies. PV modules behave like voltage sources; therefore our interest will be in voltage source type inverters. In applications where there is no grid reference, voltage control schemes are used and the inverter behaves as a voltage source. Where a grid connection is used the current control scheme is used and the inverter behaves as a current source. These inverters use the utility voltage as reference to provide the current available from the PV, and are not able to operate as an enclave [7].

Some stand-alone inverters can also be operated as grid-tied inverters or in combination with other renewable energy sources as part of hybrid power systems. Modern inverters can achieve efficiencies higher than $95 \%$ (especially grid-tied inverters) and are warranted for 5 to 10 years in most cases. Most inverters have efficiencies above $85 \%$.

\subsection{Inverter sizing}

The input rating of the inverter should never be lower than the total watt of appliances. The inverter must have the same nominal voltage as battery.

For grid connected systems, the input rating of the inverter should be same as PV array rating to allow for safe and efficient operation.

$$
\begin{gathered}
P_{\text {total }}=\left(P_{L S C}+P_{R S}\right) \times 1.25 \\
P_{\text {total }}=\text { Inverter power rating (size) } \\
P_{R S}=\text { Power of appliances running simultaneously } \\
P_{L S C}=\text { Power of large surge current appliances } \\
P_{R S}=0, P_{L S C}=8 \mathrm{kWh} \\
P_{\text {total }}=(0+12) \times 1.25 \\
=15 \mathrm{kWh}
\end{gathered}
$$


Case Study on Solar-Powered Hospital Elevator to Push Green Energy for the Use of Alternative Energy Sources-Sunlight

The inverter to be used for this system should have capacity not less than $15 \mathrm{kVA}$ and a nominal voltage of 48VDC.

\section{SOLAR CHARGE CONTROLLER SIZING}

The solar charge controller is typically rated against Amperage and Voltage capacities. Select the solar charge controller to match the voltage of PV array and batteries. Make sure that solar charge controller has enough capacity to handle the current from $\mathrm{PV}$ array. The rated current of the regulator is given by [5].

The voltage regulator selected is Xantex C60 controller 60A, $12 / 24 \mathrm{~V}$. It has nominal voltage of $12 / 24 \mathrm{VDC}$ and charging load/current of 60 amperes.

\section{BALANCE OF SYSTEM COMPONENTS}

Balance of system components includes electrical and mechanical equipments needed to construct a complete PV system and integrate the major components.
A comprehensive overview can be found in [8] BOS components may include:

$\rightarrow$ Conductors, conduits and boxes

$\rightarrow$ Over current Protection (e.g. Fuses and Breakers)

$\rightarrow$ Ground Fault Protection

$\rightarrow$ Mounting Gear (support structure)

$\rightarrow$ Disconnects

$\rightarrow$ Metering Equipment

$\rightarrow$ Maximum Power Point Trackers

\section{Brief Summary}

Table 4: Results Obtained from the Sizing of the Proposed Off-grid PV System

\begin{tabular}{|c|c|c|c|c|c|}
\hline \multirow[t]{2}{*}{ Components } & \multirow{2}{*}{$\begin{array}{l}\text { Description of } \\
\text { Components }\end{array}$} & \multicolumn{4}{|c|}{ Total Outcomes } \\
\hline & & $\begin{array}{c}\text { For } 3 \text { Hr } \\
\text { Power Failure }\end{array}$ & $\begin{array}{c}\text { For } 6 \mathrm{Hr} \\
\text { Power Failure }\end{array}$ & $\begin{array}{c}\text { For } 9 \mathrm{Hr} \\
\text { Power Failure }\end{array}$ & $\begin{array}{c}\text { For } 12 \mathrm{Hr} \\
\text { Power Failure }\end{array}$ \\
\hline $\begin{array}{l}\text { Load } \\
\text { Estimation }\end{array}$ & Total Estimated Load & $12 \mathrm{KWh}$ & $24 \mathrm{KWh}$ & $36 \mathrm{KWh}$ & $48 \mathrm{KWh}$ \\
\hline \multirow[t]{4}{*}{ PV Array } & Capacity of PV array & $3 \mathrm{KW}$ & $6.13 \mathrm{KW}$ & $9.20 \mathrm{KW}$ & $12.27 \mathrm{KW}$ \\
\hline & $\begin{array}{l}\text { Number of modules in } \\
\text { series }\end{array}$ & 2 & 2 & 2 & 2 \\
\hline & $\begin{array}{l}\text { Number of modules in } \\
\text { parallels }\end{array}$ & 9 & 17 & 26 & 34 \\
\hline & Total number of modules & 18 & 34 & 52 & 68 \\
\hline \multirow[t]{2}{*}{ Battery Bank } & Battery bank capacity & $1569 \mathrm{Ah}$ & 3138 & 4706 & 6275 \\
\hline & $\begin{array}{l}\text { Total number of batteries } \\
\text { required }\end{array}$ & 5 & 10 & 15 & 20 \\
\hline Inverter & Capacity of the inverter & $15 \mathrm{KVA}$ & $30 \mathrm{KVA}$ & $45 \mathrm{KVA}$ & $60 \mathrm{KVA}$ \\
\hline \multirow[t]{2}{*}{$\begin{array}{l}\text { Charge } \\
\text { controller }\end{array}$} & $\begin{array}{l}\text { Capacity of voltage } \\
\text { regulator }\end{array}$ & $34 \mathrm{~A}$ & $34 \mathrm{~A}$ & $34 \mathrm{~A}$ & $34 \mathrm{~A}$ \\
\hline & $\begin{array}{l}\text { Number of voltage } \\
\text { regulators required }\end{array}$ & 1 & 1 & 1 & 1 \\
\hline
\end{tabular}


Table 5: Cost Estimate of the System's Components

\begin{tabular}{|c|c|c|c|c|c|c|c|c|c|c|}
\hline \multirow[t]{2}{*}{ Component } & \multirow[t]{2}{*}{ Model } & \multirow[t]{2}{*}{$\begin{array}{l}\text { Unit } \\
\text { Price }\end{array}$} & \multicolumn{2}{|c|}{$\begin{array}{l}\text { For } 3 \mathrm{Hr} \\
\text { Power Failure }\end{array}$} & \multicolumn{2}{|c|}{$\begin{array}{c}\text { For } 6 \mathrm{Hr} \\
\text { Power Failure }\end{array}$} & \multicolumn{2}{|c|}{$\begin{array}{c}\text { For } 9 \text { Hr } \\
\text { Power Failure }\end{array}$} & \multicolumn{2}{|c|}{$\begin{array}{c}\text { For } 12 \mathrm{Hr} \\
\text { Power Failure }\end{array}$} \\
\hline & & & Qty & $\begin{array}{l}\text { Costper } \\
\text { component } \\
\text { in Rupees }\end{array}$ & Qty & $\begin{array}{l}\text { Cost per } \\
\text { component } \\
\text { in Rupees }\end{array}$ & Qty & $\begin{array}{l}\text { Cost per } \\
\text { component } \\
\text { in Rupees }\end{array}$ & Qty & $\begin{array}{l}\text { Cost per } \\
\text { component } \\
\text { in Rupees }\end{array}$ \\
\hline Modules & $\begin{array}{l}\text { ENP Sonne } \\
180 \mathrm{~W}, 24 \mathrm{~V}\end{array}$ & 6,800 & 18 & 122,400 & 34 & 231,200 & 52 & 353,600 & 68 & 462,400 \\
\hline Batteries & $\begin{array}{l}\text { ROLL12MD } \\
375 \mathrm{P}\end{array}$ & 5,100 & 5 & 25,500 & 10 & 51,000 & 15 & 76,500 & 20 & 102,000 \\
\hline $\begin{array}{l}\text { Voltage } \\
\text { Regulator }\end{array}$ & Xantrex C60 & 3,400 & 1 & 3,400 & 1 & 3,400 & 1 & 3,400 & 1 & 3,400 \\
\hline Inverter & SATCON & ------ & 1 & 3,960 & 1 & 5,800 & 1 & 7,600 & 1 & 12,650 \\
\hline $\begin{array}{l}\text { SUBTOTA } \\
\mathrm{L}\end{array}$ & (in Rupees) & & & 155,260 & & 291,400 & & 441,100 & & 580,450 \\
\hline \multicolumn{3}{|c|}{$\begin{array}{l}\text { Other BOS Costs (wires, fuses, } \\
\text { circuit breakers, etc ) }=>20 \% \text { of } \\
\text { subtotal }\end{array}$} & & 31,052 & & 58,280 & & 88,220 & & 116,090 \\
\hline $\begin{array}{l}\text { TOTAL } \\
\text { COST }\end{array}$ & (in Rupees) & & & 186,312 & & 349,680 & & 529,320 & & 696,540 \\
\hline
\end{tabular}

\subsection{RET Screen Analysis for Solar-Powered Elevator}

RET Screen is a decision-support tool designed to help decision makers and energy professionals evaluate the financial viability of renewable energy, energy efficiency and cogeneration projects around the world.The software integrates a number of databases to assist the user, including a global database of climatic conditions.

RET Screen analysis has been done to verify numerical data shown in the above table. It also expounds emission analysis as well as financial analysis for solar powered elevator. In this analysis by RET Screen we have taken a case for 3 hours power failure for a hospital elevator and estimated annual diminished emission level and economical parameters.

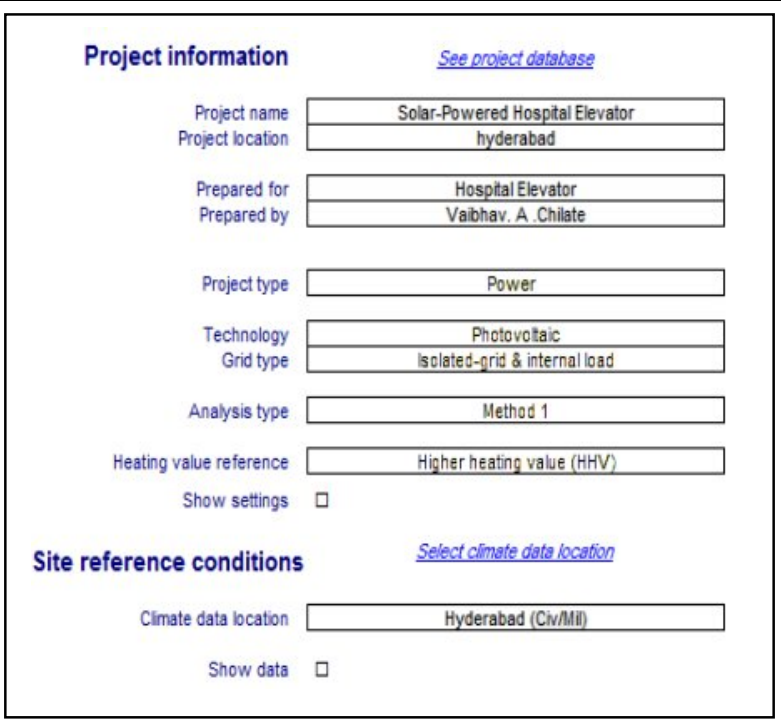

Figure 4: Solar-powered hospital elevator validation by RET Screen software 


\subsection{Emission Analysis}

The Emissions Reduction Analysis worksheet is used to estimate greenhouse gas emissions of a proposed project. Proposed case system GHG summary for solar powered elevator provides the user with an emissions profile of the proposed project; and GHG emissions reduction summary summarizes all the results listed below. The outputs of the worksheet are presented in equivalent tons of Carbon Dioxide avoided per year.

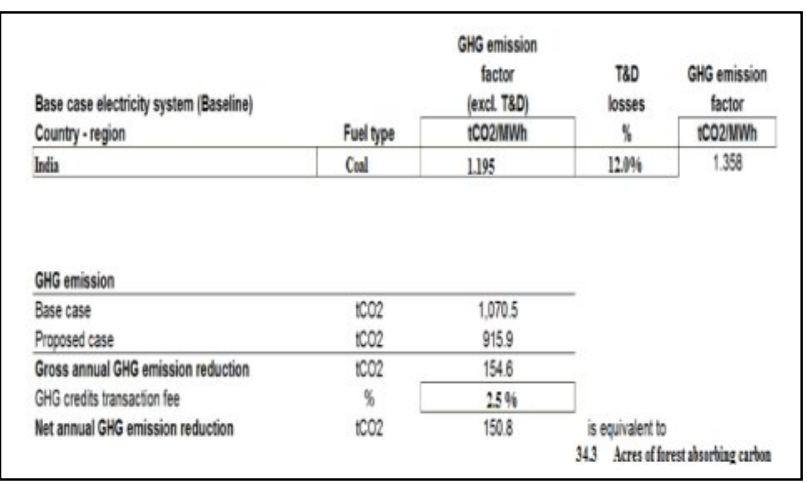

Figure 5: Emission analysis of Solar-powered hospital elevator by RET Screen software.

In this case study for 12 hours of power failure, designed photovoltaic system will save 150.8 ton carbon dioxide annually which could be compared as 34.3 acre forest absorbing carbon; which has validated by RET Screen software as shown above figure.

\subsection{Financial Analysis}

The Financial Analysis worksheet contains six sections that provide information on the flow of revenue from the project.

\begin{tabular}{|c|c|c|}
\hline \multicolumn{3}{|l|}{ Financial parameters } \\
\hline Inflation rate & $\%$ & $3 \%$ \\
\hline Project life & yr & 20 \\
\hline Debtratio & $\%$ & $70 \%$ \\
\hline Debt interest rate & $\%$ & $10.00 \%$ \\
\hline Debt term & yr & 5 \\
\hline \multicolumn{3}{|l|}{ Initial costs } \\
\hline Power system & $\delta$ & 0 \\
\hline Other & $\delta$ & 6.96 .540 \\
\hline Total initial costs & $\delta$ & $6,96,540$ \\
\hline Incentives and grants & $\delta$ & 0 \\
\hline \multicolumn{3}{|c|}{ Annual costs and debt payments } \\
\hline O\&M (savings) costs & $\delta$ & 6.000 \\
\hline Fuel cost - proposed case & $\delta$ & 0 \\
\hline \multirow[t]{2}{*}{ Deot payments - 5 yrs } & $\delta$ & $1,28,022$ \\
\hline & $\delta$ & \\
\hline Total annual costs & $\delta$ & $1,34,022$ \\
\hline
\end{tabular}

No. of Years Vs Cumulative Cash Flow

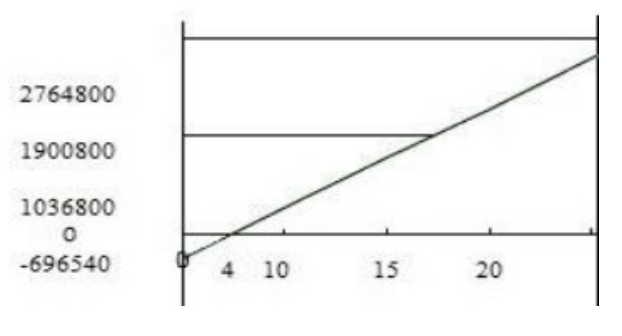

Figure 6: Financial analysis of Solar-powered hospital elevator by RET Screen software.

Under significant depth ratio of $70 \%$ with interest rate $10.00 \%$, and at an inflation rate of $03.00 \%$ above financial analysis depicts profit for solar powered elevator after 4 years which can clearly see in breakeven point. Thus, such idea of solar-powered elevator can not only save energy but also can diminish pollution as well as power charges in emergency condition.

\section{CONCLUSION}

Feasibility study with financial estimates has been carried out for powering emergency lift using solar power. RET screen based analysis shows the system reaches break even after few years of operation. The sizing of the solar power system entirely depends on the elevator load and its operational frequency. This technology ensures emergency switching to stored power at low rates.

\section{ACKKNOWLEDGEMENT}

We would like thank to Dr K Balasubramanian, Dr P.K.P. Rupa and Varanasi Sai Harsha for the continuous discussion and suggestion on this article.

\section{REFERENCES}

[1] GUIDEBOOK for Solar photovoltaic project in Philadelphia, available electronically, www.phila.gov/green/solar.html march-2011.

[2] P. Jayakumar, "Resource Assessment Handbook Prepared for APCTT", September 2009.

[3] David L. Stymiest, PE, SASHE, CEM, CHFM, Managing Hospital Emergency Power Testing Programs, 2015 American Society for Healthcare Engineering.

[4] Sandia,( 1995), "Stand-Alone Photovoltaic Systems: A Handbook of Recommended Design Practices", Sandia National Laboratories Albuquerque New Mexico. PP:1-B53

[5] Assad Abu-Jasser,(2010), "A Stand Alone Photovoltaic System, Case Study: A Residence in Gaza", Journal of Applied Sciences in Environmental Sanitation. Vol.5, PP:8191 
[6] R. Kannan, K. Leong, R. Osman, "Life Cycle Assessment" study of solar PV systems: An example of a $2.7 \mathrm{kWp}$ distributed solar PV system in Singapore", Science Direct, 2005.

[7] Grid-connected Photovoltaic Power Systems: Survey of Inverter and Related Protection Equipments, Task V,Report IEA PVPS T5-05:2002

[8] MiroZeman, Delft University of Technology, "PHOTOVOLTAIC SYSTEMS".

[9] PV System Installation and Grid-Interconnection Guidelines in Selected IEA countries, Task V, Report IEA PVPS T504:2001.

[10]J. Wiles, "Photovoltaic Systems and the 2005 National Electrical Code: Suggested Practices", Sandia National Laboratories, 2006.

[11]Amal A. Hassan, Abd El-Shafy A. Nafeh, Faten H. Fahmy and Mohamed A. El-Sayed," Stand-Alone Photovoltaic System for an Emergency Health Clinic" International Conference on Renewable Energies and Power Quality (ICREPQ'10) Granada (Spain), 23rd to 25th March, 2010. 